\title{
Balkanologie
}

Balkanologie Revue d'études pluridisciplinaires

Vol. VIII, $n^{\circ} 1$ | 2004

Volume VIII Numéro 1

\section{Bergantz (Lucien), Dix mois dans les maquis de Tito,}

Colmar : Editions Jérôme Do Bentzinger, 2002, 151 p.

Bernard Lory

\section{CpenEdition}

\section{Journals}

Édition électronique

URL : http://journals.openedition.org/balkanologie/2096

DOI : 10.4000/balkanologie.2096

ISSN : 1965-0582

Éditeur

Association française d'études sur les Balkans (Afebalk)

Édition imprimée

Date de publication : 1 juin 2004

ISSN : 1279-7952

\section{Référence électronique}

Bernard Lory, «Bergantz (Lucien), Dix mois dans les maquis de Tito, », Balkanologie [En ligne], Vol. VIII, $n^{\circ}$ 1 | 2004, mis en ligne le 21 janvier 2010, consulté le 17 décembre 2020. URL : http://

journals.openedition.org/balkanologie/2096 ; DOI : https://doi.org/10.4000/balkanologie.2096

Ce document a été généré automatiquement le 17 décembre 2020.

(c) Tous droits réservés 


\section{Bergantz (Lucien), Dix mois dans les maquis de Tito,}

Colmar : Editions Jérôme Do Bentzinger, 2002, 151 p.

\section{Bernard Lory}

\section{RÉFÉRENCE}

Bergantz (Lucien), Dix mois dans les maquis de Tito, Colmar : Editions Jérôme Do Bentzinger, 2002, $151 \mathrm{p}$.

1 Nous avons ici les souvenirs d'un jeune Alsacien, enrôlé dans la Wehrmacht comme tant d'autres "Malgré-nous » et envoyé en Bosnie occidentale à la fin de novembre 1943. Un mois plus tard, il est blessé lors d'un accrochage et capturé par les Partisans, qui, ayant reconnu sa qualité de Français, le soignent dans un hôpital de fortune caché dans la forêt. Repéré par une mission américaine, il est évacué par avion sur Bari le 5 septembre 1944. L'expérience est brève et reste assez superficielle, car sous l'uniforme, le jeune soldat ne peut pas se rendre compte de grand chose, puis, immobilisé par sa blessure, son cercle d'observation est forcément très restreint. Mais ces souvenirs ont la fraîcheur de la jeunesse (il a tout juste vingt ans) qui observe et s'imprègne de sensations dans un monde dont il ne comprend pas les tenants et les aboutissants. C'est le mémorialiste, âgé, qui s'efforce de resituer l'aventure dans le cadre de la Grande Histoire, non sans quelques pesanteurs et inexactitudes. Ce petit livre vaut par la sincérité du témoignage, qui n'est pas sans évoquer celui du médecin néo-zélandais L. Rogers ${ }^{1}$, montrant bien les difficultés et la misère de la résistance en Yougoslavie. Les illustrations en style BD sont regrettables. 


\section{NOTES}

1. Rogers (Lindsay). J'étais médecin avec Tito, Paris : Ed. France Empire, 1958. 